\title{
Analysis of the influence of partial replacement of mineral aggregate by basaltic rock dust on the production of industrialized adhesive mortar
}

\author{
๑L.C. Lentz $₫$, ${ }^{\circledR}$ E.G.P. Antunes \\ Department of Civil Engineering, University of the Extreme South of Santa Catarina (Santa Catarina, Brazil) \\ luizalentz@hotmail.com
}

Received: 28 April 2020

Accepted: 28 August 2020

Available on line: 17 March 2021

\begin{abstract}
The production of adhesive mortar uses large proportions of sand, causing undesirable environmental impact as this is a finite resource. In recent years, the insertion of civil construction waste in cement matrixes has intensified with the objective of replacing sand in the mortar manufacturing process. Therefore, in this study, the proportions of 5\%, 10\%, 15\% substitution of the mineral aggregate by basalt dust waste in the production of industrialized adhesive mortar were adopted. The reference mixture of 1:3 (cement: sand) was adopted and the water/dry material ratio was set at 0.20 . The adhesive mortars produced in the tests to determine the consistency index, water retention, mass density, open time, tensile strength and water absorption by capillarity were analyzed. The results were satisfactory, demonstrating that it is feasible to use the waste as a substitute for sand in the production of industrialized adhesive mortars.
\end{abstract}

KEYWORDS: Sustainability; Stone dust waste; Industrialized adhesive mortar; Replacement; Sand.

Citation/Citar como: Lentz, L.C.; Antunes, E.G.P. (2021) Analysis of the influence of partial replacement of mineral aggregate by basaltic rock dust on the production of industrialized adhesive mortar. Mater. Construcc. 71 [341], e240 https://doi.org/ $10.3989 / \mathrm{mc} .2021 .05420$

RESUMEN: Análisis de la influencia de la sustitución parcial del agregado mineral de polvo de roca basáltica en la producción de mortero adhesivo industrializado. La producción de mortero adhesivo utiliza grandes proporciones de arena, lo que provoca un impacto ambiental indeseable por tratarse de un recurso finito. En los últimos años se ha intensificado la inserción de residuos de construcción civil en matrices de cemento con el objetivo de sustituir la arena en el proceso de fabricación de morteros. Por lo tanto, en este estudio se adoptaron las proporciones de 5\%, 10\%, 15\% de sustitución del agregado mineral por residuos de polvo de basalto en la producción de mortero adhesivo industrializado. Se adoptó la mezcla de referencia de 1: 3 (cemento: arena) y la relación agua / material seco se fijó en 0,20 . Se analizaron los morteros adhesivos producidos en las pruebas para determinar el índice de consistencia, retención de agua, densidad de masa, tiempo abierto, resistencia a la tracción y absorción de agua por capilaridad. Los resultados fueron satisfactorios, demostrando que es factible utilizar el residuo como sustituto de la arena en la producción de morteros adhesivos industrializados.

PALABRAS CLAVE: Sostenibilidad; Residuos de polvo de piedra; Mortero adhesivo industrializado; Sustitución; Arena.

Copyright: (C2021 CSIC. This is an open-access article distributed under the terms of the Creative Commons Attribution 4.0 International (CC BY 4.0) License. 


\section{INTRODUCTION}

The ceramic industry is directly related to civil construction to the extent that the ceramic pieces can be used as cladding, internal or external, in various buildings for residential, commercial and industrial use (1). According to data from ANFACER, the National Association of Ceramic Manufacturers for Floor and Wall Coverings, Sanitary Ware and Similar (2), Brazil ranked third worldwide in production and consumption in 2016, with 706 million square meters of ceramics consumed in the same year.

The great acceptance of the product and the applicability as a ceramic tile in buildings is explained by the many advantages it has, such as ease of cleaning, durability, versatility, beauty and diversity, in addition to being a product economically affordable for all consumers (2).

The ceramic tiles are part of the Ceramic Coating System, defined as a set of bonded layers, composed of the laying of the mentioned material on a base or substrate with the aid of an adhesive mortar (3). In order to perform its role with excellence, the adhesive mortar, also known as the bonding layer, must resist the tensile and shear stresses of both interfaces, i.e., the mortar-substrate and the ceramic tile-mortar. When these stresses exceed their adhesion strength, ceramic tiles are at risk of dislaying (4).

This phenomenon happens due to the existence of empty spaces, which end up being filled with air or water, generating a complete displacement of the tile (and the consequent fall of it) with the passage of time (5). This pathological manifestation occurs frequently and has incidence both in new, newly constructed works and in old constructions, since its causes are varied (3).

The use of industrialized adhesive mortars has brought numerous benefits to civil construction in recent years such as increased labor productivity, reduced material waste as well as increased adhesion between the ceramic plate and the substrate (6).

The industrialized adhesive mortar is an industrial product, commercialized in the dry state, being named by NBR 14081-1:2012 (7) with the acronym "AC" and according to its place of application it can also receive the Roman numbers I, II or III. The industrialized adhesive mortar type I (AC I) is destined to cover floors and internal walls. Industrialized adhesive mortar type II (AC II) can be used both indoors and outdoors, and has the capacity to absorb variations in temperature and wind actions. Industrialized adhesive mortar type III (AC III) has a greater adhesion than types I and II. All these mortars can receive more the acronym "E" or "D" which refer, respectively, to adhesive mortars with extended open time and reduced sliding.

Even with a consolidated and expanding market, adhesive mortars require research on their properties, since the durability of ceramic tiles in buildings depends on the effectiveness of fixing the ceramic tiles on the substrate (3).

According to Kudo (8), adhesive mortars act as an adhesive for the laying of ceramic tiles on floors and walls, and are composed of cement (binder), natural or artificial sand and chemical additives. The quantity of these materials, nature and characteristics establish the properties of the mortars in their fresh and hard state (6).

Regarding chemical additives, most adhesive mortars are modified with hydroxyethyl cellulose (HEC) and vinyl acetate/ethylene copolymer (EVA). Both are classified as thermoplastic polymers and are added in powder form in the mixture of the anhydrous materials before being mixed with water. HEC is an additive which provides better properties for fresh mortars such as water retention. EVA is adopted in order to modify the properties of the mortar in the hardened state $(6,9)$.

According to Agopyan and John (10), Portland cement is the most consumed artificial material by man, however, it is not used alone, but together with other natural resources such as water and aggregates. According to the same authors, in Brazil, in 2009, 52 million tons of cement were produced, which were mixed with about 340 million tons of aggregates.

According to ANEPAC, the National Association of Aggregates Producers for Construction (11), in 2014 , the demand for the production of aggregates for civil construction reached 439 million tons of sand and 302 million tons of gravel. In 2017, according to data from IBRAM, the Brazilian Mining Institute (12), Brazil's annual production lost only to iron ore and mineral water.

Normally, in the formulation of adhesive mortars a fine sand is adopted as a mineral aggregate with a particle distribution of less than $0.6 \mathrm{~mm}$. In mass, this is equivalent to 50 to $70 \%$ of its formulation (8).

Therefore, the conscious use of sand becomes necessary, since nature reserves are finite. Moreover, some particularities of the material make its applicability difficult and reduce its benefits, such as the various environmental restrictions and the obligation of a series of licenses it has for its extraction, high cost with transportation and logistics, especially in places where there is no incidence of the material (13).

Thus, the growth in sand consumption and the consequent depletion of natural reserves have increased the concern for the environment and made it essential to search for new alternatives that replace natural aggregates with industrial waste in the manufacture of industrialized adhesive mortars.

The extraction and production of construction materials cause an ecological imbalance in the environment, so one must seek to reduce dependence on natural resources in order to make the whole process more sustainable (14). The civil construction 
industry generates waste that is discarded in the environment without any kind of treatment. The incorporation of these materials in cement matrixes becomes a viable option to reduce the use of their raw materials and, perhaps, to provide an increase in their properties (15).

An example is the waste resulting from the gravel production process in quarries installed on rock, called quarry fines (16). High contents of crushing filer are often formed, around 10 to $20 \%$, during the comminution of the small crushing aggregate (17). This material is sometimes used in paving works in the composition of bases, sub-bases and asphalt concrete, and its application is on a small scale. Finally, it is considered as a by-product, waste or even tailings (18).

Thus, the basalt rock dust presents itself as a possible alternative for partial replacement of sand in the production of adhesive mortars, since it is a waste discarded in the environment in large quantities without any destination or treatment. The powder is a powdery material and $100 \%$ is passed through a $30 \mu \mathrm{m}$ (micrometer) sieve.

This article aimed at developing an industrialized ACI type adhesive mortar using basalt rock dust as a partial substitute for the mineral aggregate in the proportions of 5, 10 and $15 \%$. The mortars are composed of cement, mineral aggregate, basalt powder waste and HEC and EVA additives. The open time parameters, tensile strength and water absorption by capillarity at 28 days were analyzed, as well as water retention, consistency index and mass density.

\section{MATERIALS AND METHODS}

CP-II-F-32 cement was chosen because it has low additions of pozzolanic materials. The sand, as well as the additives HEC and EVA, were granted by a mortar company in the region of Criciúma/SC, Brazil. Similarly, basalt dust waste was ceded by a crushing plant in the same region.

The sand has been submitted to the particle size composition test, determination of the compacted and loose unit mass as well as determination of the specific mass according to NM 248:2003 (19), NM 45:2006 (20) and NM 52:2009 (21), respectively. For the characterization of the waste, the X-ray diffraction (XRD), chemical analysis (FRX) and particle size analysis were performed.

In order to compare the samples of the waste and sand, the specific surface area (BET) and porosimetry (VTP) tests were also performed with the Quantachrome equipment, model Nova 1200e. Finally, the samples were photographed using a ZEISS stereoscope, model Stemi DV4. For the visualization of the sand grain shape, an increase of $320 \mathrm{X}$ was adopted while for the waste 200X was used.

The trait adopted was the proportion 1:3 (cement:sand) according to the studies of Silva et al
(22), Oliveira (6) and Póvoas and John (23). The water/dry matter ratio was obtained approximating the studies of Póvoas and John (23), Kudo, Cardoso and Pileggi (24) and Pereira, Silva and Costa (3), and the percentage of $20 \%$ was fixed. As for the additions of polymers, the percentages of $0.5 \%$ HEC and $10 \%$ EVA in relation to the mass of cement were fixed, similar to the works of Oliveira (6) and Póvoas and John (23).

As the objective of the present work is to verify the influence of the substitution of the mineral aggregate by a waste, the mortar formulation was necessary, since it would not be possible to carry out such substitution with the mortars already produced on an industrial scale. Therefore, the mixture used was based on other bibliographic studies that also formulated mortar.

In the studies of Oliveira (6) and Santos (25), both authors used a fine sand, with a value of fineness module (MF) equal to 0.74 and 0.94 , respectively. Such values are close to what is used by the companies of industrialized adhesive mortar production in the State of Santa Catarina, Brazil. Thus, in order to maintain these values of MF, the percentages of substitution of sand by waste in 5, 10 and $15 \%$ were adopted. These percentages were chosen especially because the rock dust is already very fine, so that its substitution in large percentages would reduce the fineness module of the mixture of sand plus waste, contributing to a greater demand for water in formulations.

In order to help visualize the mixtures, each sample was named according to its percentage of substitution of the mineral aggregate by the waste. Thus, for example, the sample named "REF" is the reference mixture, without any substitution. The sample called TS5, on the other hand, refers to the mixture with substitution of $5 \%$, according to the representation in Table 1.

All mortars were prepared in accordance with the requirements of NBR 14081-2:2015 (26), as well as their application in strands on the standard substrate for the determination of open time and tensile strength tests. This standard substrate also complies with the requirements established by that standard.

In the fresh state, the mortars were submitted to the tests of consistency index, mass density and water retention in accordance with NBR 13276:2016 (27), NBR 13278:2005 (28) and NBR 13277:2005 (29), respectively. In the hardened state, tests were performed to determine the open time and tensile strength, as well as the water absorption by capillarity.

The determination of the tensile strength was performed in accordance with NBR 14081-4:2012 (30). Ten ceramic plates were used which have a square section of $(50 \pm 1) \mathrm{mm}$ of edge and belong to the group BIIa, according to the classification of NBR 13817:1997 (31), with absorption of $(15 \pm 3) \%$. After 
the formation of the mortar strands, the open time of 5 min established by NBR 14081-1:2012 (7) for mortars of the ACI type was adopted in order to then carry out the laying of the ceramic plates. The adhesion tension test was performed at 28 days by manual traction with uniform speed of $(250 \pm 50) \mathrm{N} \mathrm{s}^{-1}$. Finally, the type of rupture of the plates was analyzed according to Figure 1.

The open time test followed the requirements of NBR 14081-3:2012 (33). The ceramic plates used have a square section of $(50 \pm 1) \mathrm{mm}$ of edge and belong to group BIII according to the classifications of NBR 13817:1997 (31) with absorption of $(15 \pm 3) \%$.

Finally, the determination of water absorption by capillarity was made in accordance with NBR 15259:2005 (34).

In order to analyze the results, the Analysis of Variance (ANOVA) and Tukey Test with 95\% significance was adopted to evaluate the results of determining the consistency index, water absorption by capillarity, open time and tensile strength.

\section{RESULTS AND DISCUSSIONS}

With the result of the X-ray diffractometer (XRD), represented in Figure 2, it was possible to identify the crystalline phases present in the stone powder, being them the Albite and Muscovite. The waste under study is considered an inert mineral addition, and does not exert pozzolanic activity, since there is no amorphous halo, and therefore, it is characterized as a non-reactive material (35).

The chemical analysis of the waste was performed and is presented in Table 2. The material in question is composed mainly of $\mathrm{SiO}_{2}$ (silica), $\mathrm{Al}_{2} \mathrm{O}_{3}$ (alumina) and $\mathrm{Fe}_{2} \mathrm{O}_{3}$ (hematite), and the sum of the element contents is $79.68 \%$.

Through the particle size analysis it was found that the stone dust is a material $100 \%$ passing through the sieve $30 \mu \mathrm{m}, 10 \%$ of the particles have a diameter of $1.71 \mu \mathrm{m}, 50 \%$ of $7.48 \mu \mathrm{m}$ and $90 \%$ of $16.56 \mu \mathrm{m}$, as well as an average diameter of $8.38 \mu \mathrm{m}$.

Through the granulometric composition of the sand a fineness module (FM) equal to 1 and maximum characteristic size of $0.3 \mathrm{~mm}$ was obtained. The determination of the compacted and loose unit

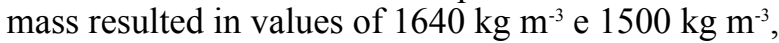

respectively. The value of the specific mass of the sand is $2,66 \mathrm{~g} \mathrm{~cm}^{-3}$.

The BET test showed that the specific surface area of the waste resulted in $4,172 \mathrm{~m}^{2} \mathrm{~g}^{-1}$, while the mineral aggregate adopted in the mixtures has a value lower than $0,226 \mathrm{~m}^{2} \mathrm{~g}^{-1}$. With the porosimetry test (VTP) it was possible to verify the volume of pores present in the materials, and the sand resulted in $0,00064 \mathrm{cc} \mathrm{g}^{-1}$ and the waste in the value of $0,01367 \mathrm{cc} \mathrm{g}^{-1}$.

The results of the consistency index test are shown in Table 3. Through ANOVA statistical analysis it was possible to verify that there were discrepancies between the groups studied and with the Tukey test it was found that the TS5 sample obtained a significant difference in relation to the REF line, and in turn the TS15 line obtained a distinct spread in comparison to the other groups.

Buyuksagis, Uygunoglu and Tatar (36) investigated the use of marble dust waste as a substitute for dolomite aggregate in adhesive mortar. All samples were produced with equal amounts of water and the results of the fresh mortar spread test showed that as the proportion of marble dust increased, the samples needed more water as the spread diameter decreased. Thus, it was found that this was a denser mortar.

Therefore, with the increased substitution of sand by stone dust, it was expected that the spreading of mortar would decrease, since the waste under study is a powdery material and would consume more kneading water. However, this behaviour is not observed in the TS5 and TS10 sample, which showed a wider spreading than the other mixtures. According to Carasek (37), the penetration of the finest grains inside the pores of the sand can occur, replacing hydration products of the cement that would form at the interface and would block the mortar. Therefore, a possible explanation for this event is that the finest grains of the waste penetrated in the permeable pores of the mineral aggregate, considering that in the porosimetry test (VTP) the sand presented a value of $0,00064 \mathrm{cc} \mathrm{g}^{-1}$. This filling of the pores makes the grain of sand even more rounded, thus reducing its specific area and causing greater spreading of the mortar. In the TS15 mixture the replacement content was higher, being able to fill the pores of sand and also to remain a part of the dispersed material, increasing the specific area.

TABLE 1. Composition of unit traits.

\begin{tabular}{cccccccc}
\hline $\begin{array}{c}\% \\
\text { replacement }\end{array}$ & Sample & Cement & Sand & Stone dust & HEC & EVA & $\begin{array}{c}\text { Water/dry } \\
\text { matter ratio }\end{array}$ \\
\hline 0 & REF & 1 & 3.00 & - & 0.005 & 0.100 & 0.20 \\
5 & TS5 & 1 & 2.85 & 0.15 & 0.005 & 0.100 & 0.20 \\
10 & TS10 & 1 & 2.70 & 0.30 & 0.005 & 0.100 & 0.20 \\
15 & TS15 & 1 & 2.55 & 0.45 & 0.005 & 0.100 & 0.20 \\
\hline
\end{tabular}




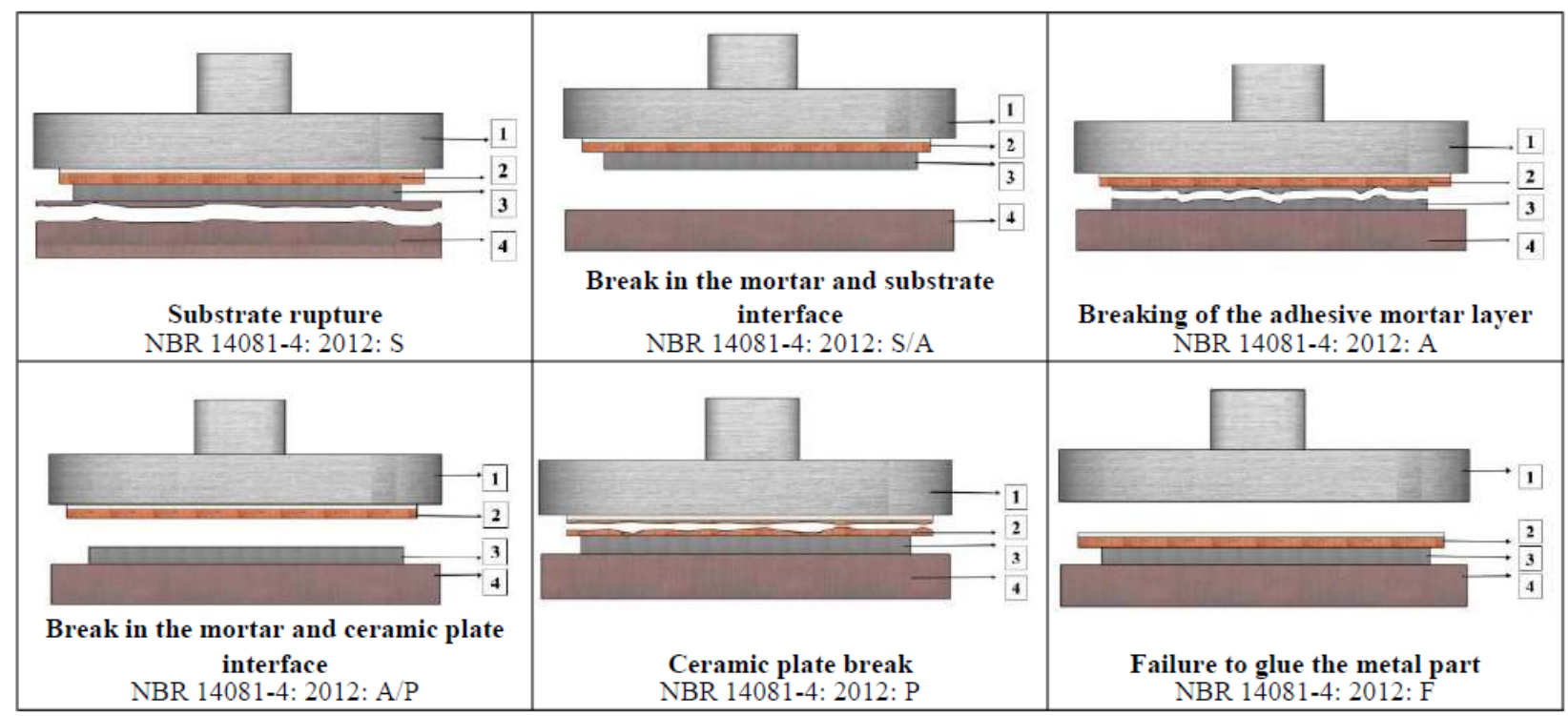

FIGURE 1. Analysis of the type of rupture (32).

With the use of the stereoscope it was possible to prove that the small aggregate used in the mortars has the most rounded grains and it was ensured that the stone powder under study is a very fine waste. Figure 3 shows the photos of the materials using the above equipment.

The results of the tests concerning the determination of water retention and mass density are shown in Table 4.

According to Silva (38), "water retention is the ability of a mortar, in its fresh state, to retain kneading water when exposed to suction from the substrate and evaporation into the environment". In determining water retention it was possible to verify that all samples obtained satisfactory results similar to Silva's studies (38), who analysed four different brands of industrialized adhesive mortars of the ACI type and obtained results above $99 \%$ water retention. Azevedo et al (39) replaced fine aggregates with granite waste in mortar production and their results indicated that a higher percentage of substitution caused an increase in water retention.
This good performance of all samples evaluated here may be related to the use of hydroxyethyl cellulose (HEC) as an additive. According to Oliveira e Silva (40) in industrialized adhesive mortars it is very common to use cellulose polymers because they are excellent water retainers. Therefore, mortars with higher percentages of water retention favor the adequate hydration of cement and make the hardening reactions continuous, thus promoting resistance gain (41).

Even so, it can be observed that the $15 \%$ substitution trait (TS15) obtained the highest percentage of water retention in relation to the reference trait. According to Bastos (42), the presence of fine particles in mortar mixtures reduces the spaces to be crossed by water, making its exit more difficult, as well as increases the total area of contact of solid particles with water, which makes the connections between the mentioned components larger. This can be verified with the values verified in the BET test, which proved that the waste has a specific area greater than sand.

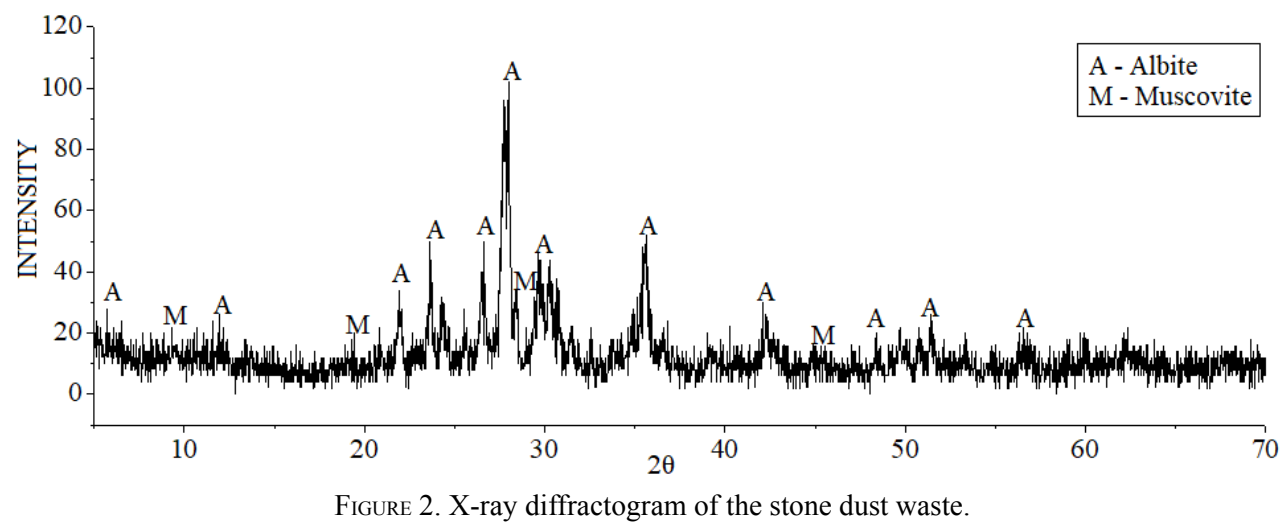


TABLE 2. Chemical analysis of basalt (FRX) dust waste.

\begin{tabular}{lclclc}
\hline Elements & Content (\%) & Elements & Content (\%) & Elements & Content (\%) \\
\hline $\mathrm{SiO}_{2}$ & 50.40 & $\mathrm{MgO}$ & 3.41 & $\mathrm{CaO}$ & 10.53 \\
$\mathrm{Al}_{2} \mathrm{O}_{3}$ & 16.63 & $\mathrm{Na}$ & 2.18 & $\mathrm{SO}_{3}$ & 0.21 \\
$\mathrm{Fe}_{2} \mathrm{O}_{3}$ & 12.65 & $\mathrm{~K}_{2} \mathrm{O}$ & 0.71 & $\mathrm{MnO}$ & 0.15 \\
$\mathrm{TiO}_{2}$ & 1.27 & $\mathrm{P}_{2} \mathrm{O}_{5}$ & 0.37 & Loss to fire & 1.50 \\
\hline
\end{tabular}

The above explanation also justifies the results of the mass density test, where it is verified that when there is an increase in the percentage of substitution of the mineral aggregate by stone dust, the mortar becomes denser, as can be observed in Table 4 . Fernández-Ledesma et al (43) used recycled concrete aggregate (ACR) as a total and partial substitute for sand in the production of mortars. According to the authors, the presence of fine particles in the ACR may increase the density of the mortar because they cause a filling effect in the cementitious matrix.

The values of water absorption by capillarity, at 10 and 90 minutes, and the capillarity coefficient are provided by Figure 4 . With the ANOVA statistical analysis and the Tukey Test, all mixtures, at both 10 and 90 minutes, have values without significant differences.

A small decrease in water absorption at 90 minutes can be observed on REF and TS5 for TS10 and TS15. According to Rato (44), the action of capillarity is related to the size, connectivity and amount of pores, and the speed of initial water absorption is greater in mortars that have large pores. That is, depending on the diameter and the quantity of capillary pores, the more they are interconnected the greater the initial water absorption (41). That is, the presence of the finest grains of stone dust, in the mixtures TS10 and TS15, propitiated a greater closing of the pores, as well as decreased their quantity, thus making the absorption of water difficult.

Figure 5 presents the result of the average adhesion strength of each sample, in $\mathrm{MPa}$, submitted to the test for determination of the open time and determination of the tensile adhesion strength.

According to NBR 14081-3: 2012 (33), for the analysis of the determination of open time, the averages need to be compared with $0.5 \mathrm{MPa}$. If the resulting value is equal to or greater than $0,5 \mathrm{MPa}$, the adhesive mortar used has an open time equal to or greater than the time adopted at the time of the mixture preparation test. Thus, analyzing the data in Figure 5, it can be observed that all mixtures exceeded this established reference value.

Through the Analysis of Variance (ANOVA) it was found that there is a difference between the groups and, according to the Tukey Test, the mixture TS10 is distinct from the REF and TS5 samples. On the other hand, the TS15 sample differed significantly from the pulling stresses of all other traits (REF, TS5 and TS10), being noticeable the decrease of its adhesion strength in comparison to the other groups. That is, the analysis shows that from $10 \%$ of sand replacement by rock dust there is an influence on the determination of open time.

As the content of sand replacement by waste increased, there was a decrease in tensile strength. With the ANOVA Analysis of Variance and the Tukey Test, it was found that the TS15 mixture again resulted in different pull-out strengths compared to the other samples and the TS10 mixture distinguished itself from the REF and TS5 sample groups. That is, the substitution above $10 \%$ influenced the result of tensile adhesion strength.

For mortars of the ACI type NBR 14081-1:2012 (7) brings as a requirement the minimum adhesion strength of $0.5 \mathrm{MPa}$ and, according to Figure 5, all mixtures meet this requirement. According to Oliveira e Silva (40), the vinyl acetate/ethylene copolymer (EVA) provides improvements in the performance of the mortars in the hardened state, such as adhesion and flexibility. In their research, the authors found that EVA was responsible for a $10 \%$ increase in the adhesion strength between the ceramic piece and the mortar.

To evaluate the results and to understand the behaviour of the adhesive mortars, not only the values of the adhesion force but also the failure or rupture patterns should be taken into consideration

TABLE 3. Consistency index.

\begin{tabular}{cccccc}
\hline Sample & Diameter 01 (mm) & Diameter 02 (mm) & Diameter 03 (mm) & Average (mm) & $\begin{array}{c}\text { Standard } \\
\text { Deviation (mm) }\end{array}$ \\
\hline REF & 213 & 212 & 214 & 213 & 1.00 \\
TS5 & 215 & 217 & 217 & 216 & 1.15 \\
TS10 & 214 & 214 & 215 & 214 & 0.58 \\
TS15 & 209 & 206 & 208 & 208 & 1.53 \\
\hline
\end{tabular}


(a)
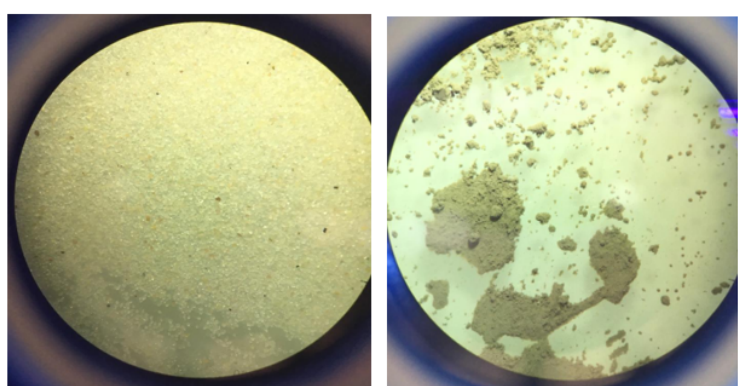

FIGURE 3. Images made with the aid of a stereoscope: (a) sand, (b) stone dust.

(45). Therefore, the types of rupture of the ten ceramic pieces tested by mixture are demonstrated in Figure 6. A similar behaviour is noted for all samples in a mixture, most of them obtained ruptures in the adhesive mortar layer (A) as well as in the ceramic mortar and plate interface $(\mathrm{A} / \mathrm{P})$.

Almeida and Sichieri (46) produced adhesive mortar with added silica and polymer. Some of their samples also obtained $\mathrm{A} / \mathrm{P}$ rupture and, according to the authors, this result indicates that the adherence of the mortar with substrate was favored due to the surface porosity.

Still in analysis of the figure, it is observed that there is an increase in the occurrence of rupture at the interface of adhesive mortar and ceramic plate $(\mathrm{A} / \mathrm{P})$ with the increase in the content of substitution of the small aggregate by stone dust. It is noticeable the decrease in the tensile strength of the mortars produced with partial replacement of sand by the waste in relation to the reference mortar, being confirmed by the data represented by Table 5, which demonstrates the percentage of $\mathrm{A} / \mathrm{P}$ rupture of the ten specimens of each mixture.

The tensile strength, according to the analysis of variance and the data presented, is reduced when the waste is used as a partial substitute for sand in the production of industrialized adhesive mortar.

Oliveira (47) used kaolin, a material with a granulometry similar to the waste studied here, as a partial

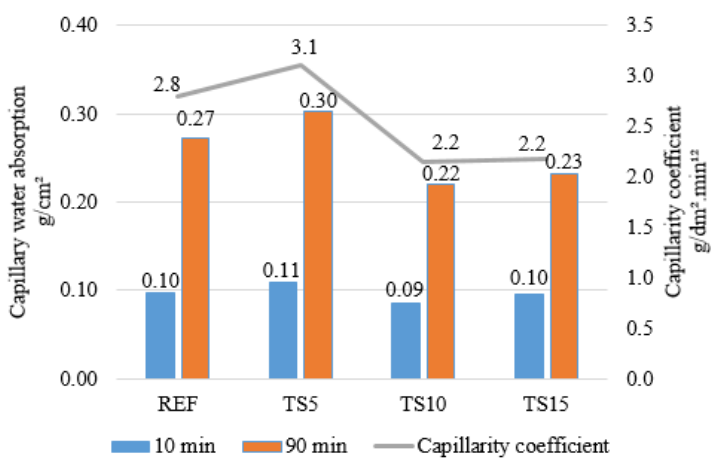

FiguRE 4. Water absorption by capillarity and capillarity coefficient
TABLE 4. Results of the test for determination of water retention and mass density.

\begin{tabular}{ccc}
\hline Sample & $\begin{array}{c}\text { Water re- } \\
\text { tention }(\%)\end{array}$ & $\begin{array}{c}\text { Mass den- } \\
\text { sity }\left(\mathbf{k g m}^{-3}\right)\end{array}$ \\
\hline REF & 99 & 1760 \\
TS5 & 99 & 1775 \\
TS10 & 99 & 1794 \\
TS15 & 100 & 1797 \\
\hline
\end{tabular}

and total substitute for sand in the production of industrialized adhesive mortar of the ACI type. Its results from pull-out stresses for the open time and tensile strength tests decreased as the small aggregate was replaced by kaolin. According to the author, the reduction in adhesion capacity over time is associated with the formation of a superficial polymeric film which interferes with the initial adhesion between the adhesive mortar and the ceramic plate.

\section{CONCLUSIONS}

The results show that the use of stone powder waste as a partial substitute for the small aggregate in the production of industrialized adhesive mortar, for the traits studied, becomes feasible.

The consistency index of samples TS5 and TS10 was higher than the REF, this increase being justified by the fine grains of the waste that penetrated the permeable pores that may exist in the sand.

Regarding the determination of water retention, all mixtures with the substitution of sand by stone dust showed similar results to industrialized market mortars and, even so, the use of fine material allowed an increase in water retention compared to the reference sample.

In the mass density test, as the small aggregate was replaced by the waste, the denser the mortar became.

The use of the waste, a very fine powdery material, has also shown satisfactory results for the absorption of water by capillarity. According to the

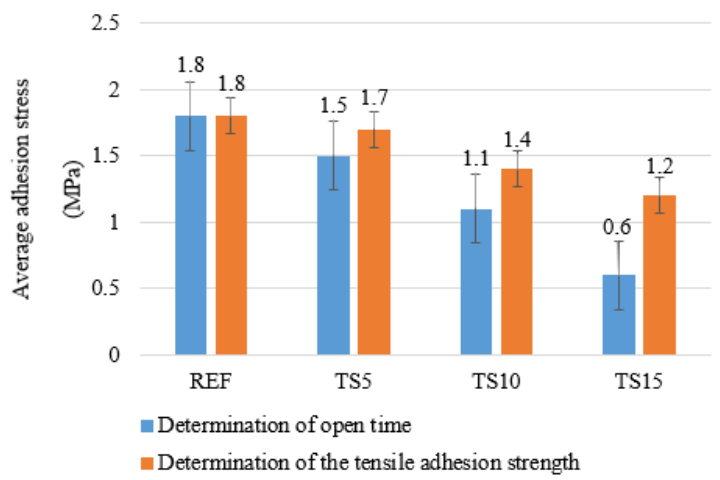

Figure 5. Test results for determination of open time and determination of tensile strength. 
(a)

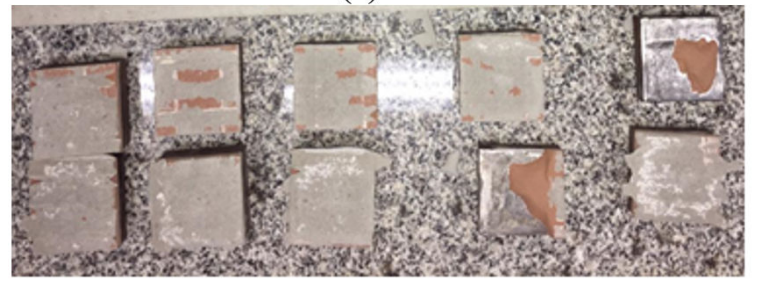

(c)

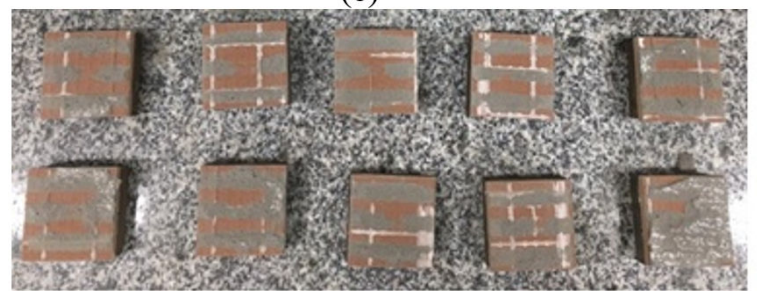

(b)

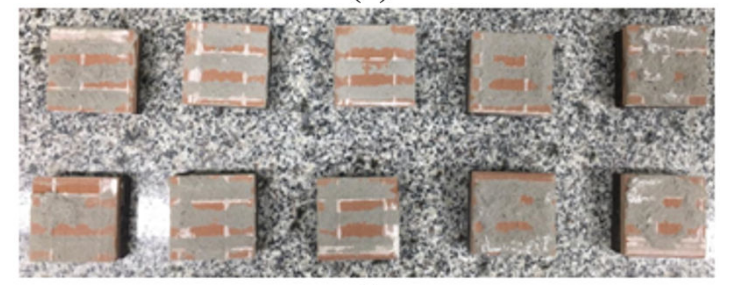

(d)

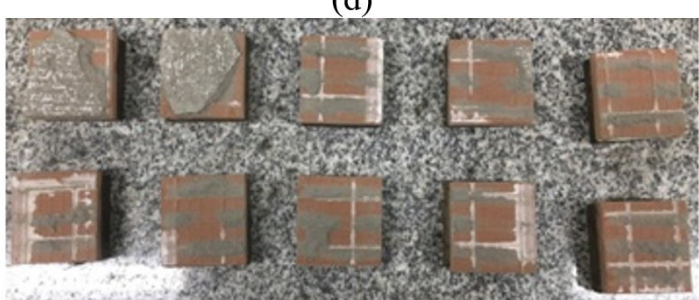

FIGURE 6. Ceramic plates after the pull-out test: (a) reference line (REF), (b) line with $5 \%$ substitution (TS5), (c) line with 10\% substitution (TS10) and (d) line with $15 \%$ substitution (TS15).

TABLE 5. Percentage of rupture at the interface adhesive mortar and ceramic plate $(\mathrm{A} / \mathrm{P})$.

\begin{tabular}{ccccc}
\hline Amostra & $\mathbf{A} / \mathbf{P}<\mathbf{5 0} \%$ & $\mathbf{5 0 \%} \leq \mathbf{A} / \mathbf{P}<\mathbf{7 5 \%}$ & $\mathbf{7 5 \%} \leq \mathbf{A} / \mathbf{P}<\mathbf{9 0 \%}$ & $\mathbf{A} / \mathbf{P} \geq \mathbf{9 0 \%}$ \\
\hline REF & 2 & - & - & - \\
TS5 & 7 & 3 & - & - \\
TS10 & 6 & 4 & - & - \\
TS15 & 2 & 4 & 4 & - \\
\hline
\end{tabular}

statistical analysis, the groups had no significant variance and were similar to each other.

Regarding the determination of open time and tensile strength, both tests obtained similar behaviors. While the content of sand replacement by stone dust was increased, there was a reduction in the tensile bond strength. Even with this reduction, the strengths exceeded the values stipulated by norm. Finally, the substitutions above $10 \%$ influenced the cited results.

At last, it is recommended for future work to verify the appearance of pathological manifestations in the mortars using the waste, since the stone powder showed in its chemical analysis the presence of salts $\left(\mathrm{Na}_{2} \mathrm{O}\right)$, which in the future may cause the appearance of efflorescence. In practice, it is common not to use EVA in the composition of ACI type adhesive mortars, so it is indicated to carry out new studies with mixtures without the addition of EVA.

\section{REFERENCES}

1. Oliveira, A.P.N.; Hotza, D. (2015). Ceramic tile manufacturing technology. 2 ed. UFSC Publisher.

2. ANFACER, National Association of Ceramic Manufacturers for Coatings, Sanitary Ware and the Like. (2016). Guidance Sectorial Manual for Compliance with ABNT NBR 15575: 2013 Performance Standard. 1 ed.

3. Pereira, E.; da Silva, I.J.; Maron da Costa, M.R.M. (2013) Evaluation of adherence mechanisms between adhesive mortars and non-porous surface. Ambient. Constr. 13,
139-149. https://doi.org/10.1590/S1678-8621201300020 0011.

4. Ribeiro, F.A. Specification of movement joints in facade cladding: state of the art survey, master's thesis, Polytechnic School, University of São Paulo (2006).

5. Lourenço, T.; Matias, L.; Faria, P. (2017) Anomalies detection in adhesive wall tiling systems by infrared thermography. Construc. Build. Mater. 148, 419-428. https://doi.org/10.1016/j.conbuildmat.2017.05.052.

6. Oliveira, J. Study of the properties of adhesive mortars submitted to saturation and drying, master's thesis, Federal University of Santa Catarina (2004).

7. Brazilian Association of Technical Standards. (2012). NBR 14081-1: Industrialized adhesive mortar for laying ceramic tiles. Part 1: Requirements.

8. Kudo, E.K. Rheological characterization of adhesive mortars, master's thesis, Polytechnic School, University of São Paulo (2012).

9. Silva, D.A.; John, V.M.; Ribeiro, J.L.D.; Roman, H.R (2001) Pore size distribution of hydrated cement pastes modified with polymers. Cem. Concr. Res. 31, 1177-1184. https://doi.org/10.1016/S0008-8846(01)00549-X.

10. Agopyan, V.; John, V.M. (2011). The challenge of sustainability in civil construction. 2 ed [5]. Edgard Blucher Ltda.

11. ANEPAC, National Association of Entities of Producers of Aggregates for Construction: Market - Perspectives for the Aggregates Sector. (2014). Available at: https:// www.anepac.org.br/agregados/mercado. Access in: 03 set. 2019.

12. IBRAM, Brazilian Mining Institute: Mining is present in the realization of the dream of home ownership. (2018). Available at: <http://portaldamineracao.com.br/ibram/ mineracao-esta-presente-na-realizacao-do-sonho-da-casapropria/>. Access in: 03 set. 2019.

13. Damo, G.F. Evaluation of the performance of different small crushing aggregates in Portland cement concrete, master's thesis, Federal University of Santa Catarina (2011). 
14. Kabeer, K.I.S.A.; Vyas, A.K. (2018) Utilization of marble powder as fine aggregate in mortar mixes. Construc. Build. Mater. 165, 321-332. https://doi.org/10.1016/j.conbuild mat.2018.01.061.

15. Garcez de Azevedo, A.R.; Alexandre, J.; Zanelato, E.B.; Marvila, M.T. (2017) Influence of incorporation of glass waste on the rheological properties of adhesive mortar. Construc. Build. Mater. 148, 359-368. https://doi.org/ 10.1016/j.conbuildmat.2017.04.208

16. D'Agostino, L. Z.; Soares, L. (2003). The use of granitegneiss rock quarry fines to replace natural sands in the preparation of mortar. Geosci. Magaz. 22, 65-73.

17. de Sousa Kazmierczak, C.; Rosa, M.; Arnold, D. C. M (2016) Influence of crushed aggregates filler on the properties of rendering mortar. Ambient. Constr. 16, 7-19. https://doi.org/10.1590/s1678-86212016000200076.

18. Campos, H.F. High-strength concrete using stone dust as partial replacement for Portland cement: experimental study, master's thesis, Federal University of Paraná (2015).

19. Brazilian Association of Technical Standards. (2003) NBR NM 248: Aggregates - Determination of the granulometric composition.

20. Brazilian Association of Technical Standards. (2006) NBR NM 45: Aggregates - Determination of unit mass and void volume.

21. Brazilian Association of Technical Standards. (2009) NBR NM 52: Small aggregate - Determination of specific gravity and apparent specific mass.

22. Silva, D.A.; Fredel, M.C.; Roman, H.R.; Alarcon, O.E. (1998) Influence of polymer content on the properties of adhesive mortars. VII National Meeting of Built Environment Technology.

23. Póvoas, Y.V.; John, V.M. Evaluation of film formation in adhesive mortar, Technical bulletin, Polytechnic School, University of São Paulo (2006).

24. Kudo, E.K.; Cardoso, F.A.; Pileggi, R.G. (2013) Evaluation of adhesive mortars by rotational rheometry. Ambient. Constr. 13, 125-137. https://doi.org/10.1590/ S1678-86212013000200010.

25. Santos, N. Evaluation of micro and nanoporosity of adhesive mortars, master's thesis, Federal University of Santa Catarina (2006)

26. Brazilian Association of Technical Standards. (2015) NBR 14081-2: Adhesive mortars industrialized for the settlement of ceramic tiles. Part 2: Execution of the standard substrate and application of the fresh mortar for tests.

27. Brazilian Association of Technical Standards. (2016) NBR 13276: Mortars applied on walls and ceilings Determination of the consistence index.

28. Brazilian Association of Technical Standards. (2005) NBR 13278: Mortars applied on walls and ceilings Determination of the specific gravity and the air entrained content in the fresh stage.

29. Brazilian Association of Technical Standards. (2005) NBR 13277: Mortars applied on walls and ceilings Determination of the water retentivity.

30. Brazilian Association of Technical Standards. (2012). NBR 14081-4: Adhesive mortars industrialized for the settlement of ceramic tiles. Part 4: Determination of the bond tensile strength.

31. Brazilian Association of Technical Standards. (1997). NBR 13817: Ceramic coating plates - Classification.

32. Antunes, E.G.P. Evaluation of the effects of humidity expansion (EPU) of ceramic tiles on the durability of internal ceramic tile systems, doctoral dissertation, Federal University of Santa Catarina (2019).

33. Brazilian Association of Technical Standards. (2012). NBR 14081-3: Adhesive mortars industrialized for the settlement of ceramic tiles. Part 3: Determination of the open time.

34. Brazilian Association of Technical Standards. (2005). NBR 15259: Mortars applied on walls and ceilings Determination of water absorption coefficient due to capilary action.

35. Hoppe Filho, J.; Gobbi, A.; Pereira, E.; Quarcioni, V.A.; de Medeiros, M.H.F. (2017) Pozzolanic activity of mineral additions for Portland cement (Part I): Pozzolanic activity index with lime (PAI), X-ray diffraction (XRD), thermogravimetry (TG/DTG) and modified Chapelle. Maté 22 [3]. https://doi.org/10.1590/s1517-707620170003.0206.

36. Buyuksagis, I.S.; Uygunoglu, T.; Tatar, E. (2017) Investigation on the usage of waste marble powder in cement-based adhesive mortar. Construc. Build. Mater. 154, 734-742. https://doi.org/10.1016/j.conbuildmat.2017. 08.014

37. Carasek, H. (2007). Chapter 26: Mortars. In: Isaia, G.C. Civil Construction Materials and Principles of Materials Science and Engineering. v2, IBRACON.

38. Silva, C.O. Critical analysis of the requirements and quality criteria for adhesive mortar, master's thesis, Polytechnic School, University of São Paulo (2003).

39. Garcez de Azevedo, A.R.; Teixeira Marvila, M.; da Silva Barroso, L.; Zanelato, E.B.; Alexandre, J.; de Castro Xavier, G.; Neves Monteiro, S. (2019) Effect of granite residue incorporation on the behavior of mortars. Materials. 12, 1449. https://doi.org/10.3390/ma12091449.

40. Oliveira, J.; Silva, D.A. (2005) Effect of saturation and post-saturation drying on the adhesion between adhesive mortars and porcelain tiles. Brazilian Symposium on Mortar Technology

41. Mattana, A.J.; Farias de Medeiros, M.H.; Gonçalves da Silva, N.; de Mello Maron da Costa, M.R. (2012) Analytic hierarchy process to choose between natural aggregate and crushed rock sand for producing coating mortar. Ambient. Constr. 12, 63-79. https://doi.org/10.1590/S1678-86212 012000400006.

42. Bastos, P.K.X. Retraction and development of mechanical properties of mixed coating mortars, doctoral dissertation, Polytechnic School, University of São Paulo (2001).

43. Fernández-Ledesma, E.; Jiménez, J. R.; Ayuso, J.; Corinaldesi, V.; Iglesias-Godino, F. J. (2016) A proposal for the maximum use of recycled concrete sand in masonry mortar design. Mater. Construcc. 66 [321], e075. https:// doi.org/10.3989/mc.2016.08414

44. Rato, V.N.P.M. Influence of morphological microstructure on the behaviour of mortars, doctoral dissertation, New University of Lisbon (2006)

45. Modolo, R.C.E.; Silva, T.; Senff, L.; Tarelho, L.A.C.; Labrincha, J.A.; Ferreira, V.M.; Silva, L. (2015). Bottom ash from biomass combustion in BFB and its use in adhesive-mortars. Fuel Proces. Technol. 129, 192-202. http://doi.org/10.1016/j.fuproc.2014.09.015.

46. Almeida, A. E. F. S.; Sichieri, E. P. (2007). Experimental study on polymer-modified mortars with silica fume applied to fix porcelain tile. Build. Environ. 42, 2645-2650. http://doi.org/10.1016/j.buildenv.2006.07.002.

47. Oliveira, G.C. Development of adhesive mortar using kaolin residue, doctoral dissertation, Federal University of Campina Grande, (2016). 